\title{
Pengaruh Jumlah Bahan Baku serta Waktu Ekstraksi terhadap Karakteristik dan Umur Simpan Ekstrak Stevia Cair
}

\author{
The Effect of Material Amount and Extraction Time to Liquid Stevia's Characteristics and Shelf-life \\ Zulfaa Irbah Zain ${ }^{1 \star}$, Sarifah Nurjanah², Bambang Nurhadi \\ 1,2Departemen Teknik Pertanian dan Biosistem, FTIP Universitas Padjadjaran \\ ${ }^{3}$ Departemen Teknologi Industri Pangan, FTIP Universitas Padjadjaran \\ Jl. Raya Bandung-Sumedang Km 21 Jatinangor, Bandung, 40600, Indonesia \\ *E-mail: zulfaa.zain@gmail.com
}

Diterima: 14 Agustus 2019; Disetujui: 15 Desember 2020

\begin{abstract}
ABSTRAK
Kebutuhan akan bahan tambahan pemanis semakin meningkat seiring dengan pertumbuhan industri pangan. Salah satu jenis pemanis alami yang belum banyak dikembangkan adalah Stevia rebaudiana Bertonii. Daun stevia dapat diekstrak dengan air. Penelitian ini bertujuan untuk mengetahui pengaruh formulasi ekstraksi yang menghasilkan karakteristik ekstrak paling baik. Rancangan yang digunakan adalah Rancangan Acak Lengkap dengan faktor rasio bahan baku:pelarut (b/v) dan faktor waktu ekstraksi. Daun stevia dikeringkan pada suhu $55^{\circ} \mathrm{C}$ selama 5 jam dan diekstrak menggunakan water bath pada suhu $95^{\circ} \mathrm{C}$ dengan air sebagai pelarut. Variasi perlakuan rasio bahan baku:pelarut yang digunakan sebesar 1:25, 1:30, dan 1:35 (b/v), dengan variasi waktu ekstraksi sebesar 20, 30, dan 40 menit. Karakteristik yang diamati diantaranya adalah total padatan terlarut, kecerahan, kadar steviosida, dan kemanisan dengan metode uji ranking. Selain itu dilakukan pula pengujian tingkat kemanisan terhadap gula pasir dengan metode magnitude estimation dan pengujian umur simpan dengan sensory shelf-life estimation. Hasil penelitian ini menunjukkan bahwa ekstraksi dengan perlakuan rasio bahan baku:pelarut 1:25 (b/v) dan waktu ekstraksi 40 menit menghasilkan karakteristik paling baik dengan nilai total padatan terlarut sebesar 2 oBrix, nilai kecerahan sebesar 8,52, kadar steviosida sebesar 2,82\%, dan nilai rata-rata kemanisan sebesar 3,33 . Pada penelitian ini diketahui bahwa ekstrak stevia memiliki tingkat kemanisan 120 kali dari gula pasir, serta umur simpan 12,531 hari.
\end{abstract}

Kata kunci: stevia, ekstraksi, jumlah bahan baku, waktu ekstraksi

\begin{abstract}
The demand of sweetener as food additive increases along with the growth of food industry. Stevia rebaudiana Bertonii is one of alternative natural sweetener which has not been utilized optimally yet. This study investigated the ratio formulation between Stevia rebaudiana Bertonii and the solvent as the raw material and time extraction to provide the best extract characteristics. A completely random design was used as the design experiment with 9 treatments and replications. The variation of material and solvent amount ratio $(w / v)$ were of 1:25, 1:30, and 1:35 while extraction time were 20, 30, and 40 minutes. The characteristics observed were total dissolved solids, brightness, stevioside content, and sweetness by ranking test method. Furthermore, the sweetness level and shelf-life of extract tests were also carried out by magnitude estimation and sensory shelf-life estimation respectively. The results revealed that the ratio of material and solvent amount of 1:25 (w/v) along with extraction time of 40 minutes showed the best characteristics with total dissolved solids amount of $2^{\circ}$ Brix, brightness amount of 8.52, stevioside content of $2.82 \%$, and average sweetness of 3.33 . The extract of Stevia rebaudiana Bertonii was also 120 times sweeter than sugar cane with shelf-life period of 12.531 days.
\end{abstract}

Keywords: stevia, extraction, raw material, extraction time

\section{PENDAHULUAN}

Pemanis merupakan salah satu bahan tambahan pangan yang digunakan untuk membangkitkan persepsi rasa manis. Pemanis didapatkan dalam bentuk alami maupun buatan. Gula pasir (sukrosa) merupakan salah satu pemanis alami yang banyak dikonsumsi. Di Indonesia, konsumsi gula pasir pada tahun 2019 diperkirakan akan mencapai mencapai 7,1 juta ton atau 26,58 kilogram per kapita (Organization for Economic Cooperation and Development, 2018). Disamping itu, gula pasir memiliki kelemahan atas nilai kalorinya yang tinggi. Menurut United States Department of Agriculture (2015), rata-rata penduduk Amerika mendapatkan 270 kalori dari konsumsi gula setiap harinya. Mengkonsumsi makanan dengan asupan kalori tinggi dapat menyebabkan gangguan metabolis (Thomas and Glade, 2010), untuk itu pemanis sintetis diproduksi sebagai alternatif gula pasir karena nilai kalorinya yang rendah, namun hasil metabolisme beberapa pemanis sintetis dapat bersifat karsinogenik (Whitehouse et al., 2008).

Stevia rebaudiana B. merupakan tanaman penghasil rasa manis alami yang berpotensi sebagai pemanis alternatif bagi gula pasir dan pemanis sintetis karena nilai kalorinya yang rendah (Gasmalla et al., 2013) dan kemanisan yang sangat tinggi. Rasa manis tanaman 
stevia dihasilkan dari berbagai macam glikosida, dimana steviosida merupakan komponen glikosida terbesar (Kinghorn, 2002). Ketika daun stevia diekstrak, komponen steviosida meningkat, sehingga rasa manis ekstrak akan meningkat. Ekstraksi dapat dilakukan dengan sederhana dengan merebus daun stevia dengan air pada water bath. Air dipilih sebagai pelarut karena dapat menghasilkan konsentrasi steviosida lebih tinggi (Chandra, 2015), dan lebih aman dan halal dibandingkan dengan pelarut lainnya. Perebusan dipilih sebagai metode ekstraksi karena adanya penambahan panas dapat meningkatkan laju ekstraksi, sehingga ekstrak dapat dihasilkan lebih banyak dalam waktu yang lebih singkat (Wahyuni, 2016).

Selain dipengaruhi oleh jenis pelarut dan metode ekstraksi, ekstraksi daun stevia juga dipengaruhi oleh jumlah bahan baku dan waktu ekstraksi (Wuryantoro dan Susanto, 2014). Untuk mengetahui pengaruh faktor tersebut dalam ekstraksi stevia, maka diperlukan penelitian untuk mengetahui jumlah bahan baku dalam pelarut dan waktu ekstraksi yang paling tepat untuk menghasilkan karakteristik ekstrak stevia paling baik, khususnya pada karakteristik kemanisan. Selain itu, diberikan juga pengujian tingkat kemanisan ekstrak stevia cair terhadap gula pasir dan pengujian umur simpan untuk mengetahui waktu dimana ekstrak stevia cair sudah tidak dapat diterima oleh konsumen.

\section{METODOLOGI}

\section{Alat dan Bahan}

Bahan baku yang digunakan untuk penelitian adalah 3 kilogram daun stevia segar jenis Stevia rebaudiana B. yang diperoleh dari lahan perkebunan di Bogor, Jawa Barat, dan air sebanyak 20 liter sebagai pelarut. Bahan kimia yang digunakan diantaranya adalah asetonitril. Peralatan yang digunakan meliputi labu Erlenmeyer, oven blower, timbangan, dan water bath. Alat yang digunakan untuk analisis sampel diantaranya adalah liquid chromatography-mass spectroscopy (LC-MS), refraktometer, dan spektrofotometer.

\section{Persiapan Daun Stevia}

Daun stevia segar disortasi secara manual, dimana daun stevia yang dipilih adalah daun yang berwarna hijau, tidak layu, dan tidak berlubang. Daun stevia yang telah disortasi kemudian dicuci dengan air mengalir, kemudian dikeringanginkan pada tempat yang tidak terkena sinar matahari secara langsung selama \pm 1 jam, kemudian daun stevia dikeringkan pada oven blower dengan suhu $55^{\circ} \mathrm{C}$ selama 5 jam (Muliana, 2017).

\section{Ekstraksi Daun Stevia}

Terdapat dua faktor perlakuan pada ekstraksi daun stevia, yaitu faktor perbandingan bahan baku dengan pelarut sebesar 1:25, 1:30, dan 1:35 (b/v), serta faktor waktu ekstraksi sebesar 20, 30, dan 40 menit, sehingga terdapat sembilan kombinasi perlakuan ekstraksi (Wuryantoro dan Susanto, 2014). Daun stevia yang telah dikeringkan dicampurkan dengan 400 mililiter air dengan rasio daun stevia yang telah ditentukan, kemudian diekstraksi pada water bath dengan suhu $95^{\circ} \mathrm{C}$ dan waktu yang telah ditentukan, dan disaring untuk mendapatkan ekstrak cair.

\section{Analisis Kadar Air}

Analisis kadar air dilakukan pada daun stevia segar dan daun stevia kering menggunakan metode termogravimetri (AOAC, 1999). Cawan dikeringkan pada oven dengan suhu $105^{\circ} \mathrm{C}$ selama 30 menit, dan ditimbang. Sampel sebanyak 5 gram dimasukkan pada cawan, dikeringkan selama 3 jam, kemudian ditimbang. Sampel pada cawan dikeringkan kembali selama 1 jam hingga berat sampel menjadi konstan. Kadar air yang dihitung adalah kadar air basis basah. Perhitungan kadar air terdapat pada Persamaan 1.

Kadar air (basis basah) $=\frac{w-(w 1-w 2)}{w} \times 100 \%$

keterangan:

$\mathrm{w} \quad=$ massa sampel awal (gram)

$\mathrm{w}_{1} \quad$ = massa sampel dan cawan kering (gram)

$\mathrm{w}_{2}=$ massa cawan (gram)

\section{Analisis Rendemen Parsial dan Total}

Nilai rendemen parsial yang dihitung antara lain adalah rendemen sortasi, pencucian, pengeringan, ekstraksi, dan penyaringan. Nilai rendemen parsial dan total didapatkan dari perbandingan berat bahan hasil dengan berat bahan sebelum proses. Perhitungan nilai rendemen terdapat pada Persamaan 2.

Rendemen $=\frac{\text { massa setelah proses }(\mathrm{gram})}{\text { massa sebelum } \text { proses }(\mathrm{gram})} \times 100 \%$

\section{Analisis Total Padatan Terlarut}

Analisis total padatan terlarut dilakukan dengan refraktometer (Yenrina, 2015). Ekstrak stevia diteteskan pada plat, dan hasil dalam satuan 'Brix akan terbaca ketika alat diarahkan pada arah cahaya.

\section{Analisis Warna}

Analisis warna dilakukan dengan spektrofotometri dengan sistem warna CIELAB (Hunter Associates Laboratory, 2010). Ekstrak stevia dimasukkan pada wadah bening, kemudian hasil berupa L (lightness atau kecerahan warna), a (merah dan hijau), b (biru dan kuning), $\mathrm{C}$ (chrome atau intensitas warna), dan $\mathrm{H}$ (hue atau rona warna) akan terbaca pada komputer yang terhubung dengan spektrofotometri.

\section{Analisis Steviosida}

Pengukuran kadar steviosida dalam ekstrak daun stevia dilakukan dengan menggunakan liquid chromatography-mass spectroscopy (LC-MS) (Shah et al., 2012). Pendeteksi atau detektor untuk LC-MS adalah mass spectroscopy. Detektor ini akan mendeteksi senyawa berdasarkan berat molekul. Steviosida memiliki rumus kimia $\mathrm{C}_{38} \mathrm{H}_{60} \mathrm{O}_{18}$ sehingga berat molekulnya adalah 804,8722 (Kinghorn, 2002). Hasil deteksi diberikan dalam bentuk kromatogram.

\section{Analisis Kemanisan}

Analisis kemanisan dilakukan dengan uji organoleptik berupa uji ranking (Lawless dan Heymann, 2010). Ekstrak stevia cair diencerkan dengan air hingga memiliki konsentrasi 5\% (v/v), kemudian diberikan kode, dan disajikan secara acak pada 30 panelis. Panelis akan diminta untuk mengurutkan sampel berdasarkan kemanisannya dari nomor urut 1 hingga 9, dimana nomor 1 adalah sampel yang memiliki kemanisan paling tinggi, dan seterusnya.

\section{Analisis Kesamaan Kemanisan}

Analisis kemanisan dilakukan dengan metode magnitude estimation (Cardello et al., 1999). Gula pasir (sukrosa) dengan konsentrasi $10 \%(\mathrm{~b} / \mathrm{v})$ digunakan sebagai sampel kontrol. Ekstrak stevia digunakan 
sebagai sampel pembanding memiliki konsentrasi 4,7 , 10,13 , dan $16 \%(\mathrm{~b} / \mathrm{v})$. Panelis diminta untuk memperkirakan intensitas rasa manis dari kelima konsentrasi ekstrak stevia. Nilai sampel kontrol adalah 100, jika kemanisan ekstrak stevia dua kali lipat lebih manis dari sampel kontrol, maka panelis akan memberikan nilai 200, namun jika kemanisan ekstrak stevia setengah kali lebih maniis dari sampel kontrol, maka panelis akan memberikan nilai 50 .

\section{Analisis Umur Simpan}

Analisis umur simpan dilakukan dengan metode sensory shelf-life estimation (Gimenez et al., 2012). Ekstrak stevia cair disimpan selama 28 hari dan dievaluasi dengan reversed design, dimana sampel dibuat pada hari ke-0, ke-7, ke-14, ke-21, dan ke-28. Pada hari ke 28, 10 orang panelis terlatih akan menganalisis peningkatan kepahitan dan peningkatan warna gelap dari ekstrak dengan skala tak terstruktur dengan nilai 0-15.

Hasil pengamatan antara lama penyimpanan dengan penurunan mutu diplotkan pada plot Orde Nol dan Orde Satu. Plot Orde Nol dilakukan antara lama penyimpanan (hari) dan penurunan mutu (k), sedangkan plot Orde Satu dilakukan antara lama penyimpanan dan bentuk lon dari penurunan mutu. Nilai regresi yang terbesar dari kedua plot ordo akan menjadi orde reaksi yang digunakan. Hasil persamaan linear dari plot dapat dihubungkan dengan general rate law (Toledo, 1991). Persamaan dan internal general rate law untuk Ordo Nol dan Ordo Satu berturutturut terdapat pada Persamaan 3 dan 4.

$C_{t}=k t+C_{0}$

$\ln C_{t}=k t+\ln C_{0}$

\section{HASIL DAN PEMBAHASAN}

\section{Persiapan Daun Stevia}

Daun stevia dipilih sebagai bahan baku ekstraksi karena kadar steviosida pada daun lebih tinggi dibandingkan dengan bagian tanaman stevia lainnya (Wuryantoro dan Susanto, 2014). Proses pencucian perlu dilakukan karena daun stevia merupakan tanaman semak yang tidak tinggi, sehingga banyak kotoran seperti tanah yang menempel pada daun teresebut. Daun stevia kemudian dikeringanginkan untuk menghilangkan air yang menempel pada proses pencucian, dan dikeringkan dengan oven blower pada suhu $55^{\circ} \mathrm{C}$ selama 5 jam. Pengeringan daun stevia dilakukan untuk meningkatkan kadar steviosida atau kadar kemanisan dari ekstrak stevia (Lemus-Mondaca et al., 2015).

\section{Ekstraksi Daun Stevia}

Ekstraksi daun stevia dilakukan dengan pelarut air. Air dianggap lebih aman penggunaannya dibandingkan dengan pelarut lainnya seperti etanol dan metanol. Daun stevia kering sebanyak 16 gram untuk rasio 1:25, 13,33 gram untuk rasio 1:30, dan 11,42 gram untuk rasio 1:35 disiapkan, dan dicampurkan dengan air sebanyak 400 mililiter pada labu Erlenmeyer, kemudian direbus pada water bath dengan suhu $95^{\circ} \mathrm{C}$ selama 20,30 , dan 40 menit. Proses penyaringan perlu dilakukan setelah perebusan untuk memisahkan ampas daun dengan ekstrak cair. Penyaringan dilakukan dengan corong dan kertas saring.

\section{Hasil Kadar Air}

Sebelum dan sesudah proses pengeringan, kadar air daun stevia dianalisis dengan metode gravimetri. Hasil kadar air daun stevia segar dan daun stevia kering terdapat pada Tabel 1.

Tabel 1. Kadar Air Daun Stevia Segar dan Kering

\begin{tabular}{ccc}
\hline \multirow{2}{*}{ Cawan } & $\begin{array}{c}\text { Kadar Air Daun } \\
\text { Segar }(\%)\end{array}$ & $\begin{array}{c}\text { Kadar Air Daun } \\
\text { Kering }(\%)\end{array}$ \\
\hline 1 & 74,72 & 4,32 \\
2 & 74,53 & 4,53 \\
3 & 74,91 & 4,27 \\
\hline Rata-rata & $74,72 \pm 0,19$ & $4,37 \pm 0,13$ \\
\hline
\end{tabular}

Kadar air daun stevia yang digunakan berpengaruh terhadap rasa dan waktu simpan bahan. Kadar air daun yang digunakan pada proses ekstraksi harus kurang dari $10 \%$ untuk meminimalisir pertumbuhan bakteri yang menyebabkan pembusukan dan enzim yang menyebabkan daun berubah warna menjadi kecoklatan (Marlina dan Widiastuti, 2018). Pada penelitian ini, kadar air daun stevia segar rata-rata mencapai $74,72 \%$, dan kadar air daun stevia kering rata-rata mencapai $4,37 \%$. Kondisi ini menandakan daun stevia kering telah dapat diproses pada tahapan berikutnya.

\section{Hasil Rendemen Parsial dan Total}

Hasil rendemen didapatkan dari perbandingan bobot pada setiap tahap penelitian. Data rendemen pada proses persiapan daun stevia dan proses ekstraksi disajikan pada Gambar 1 dan 2.

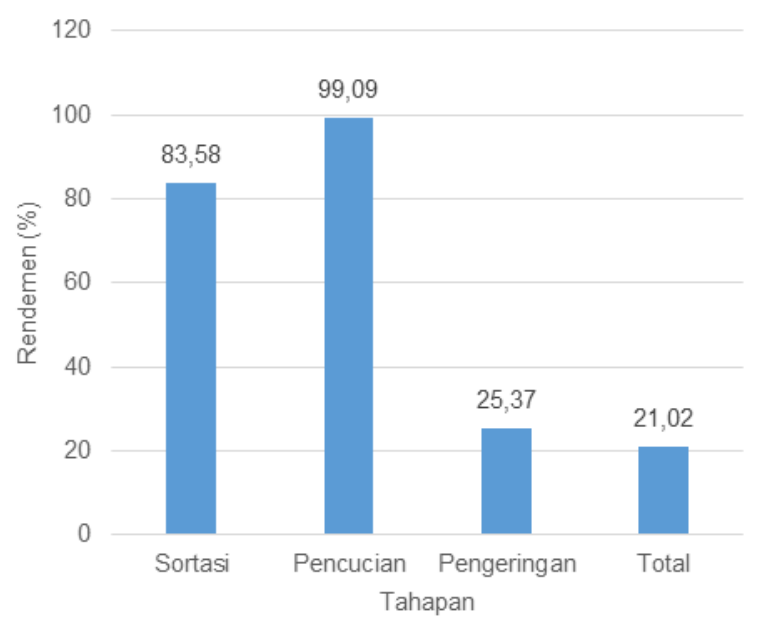

Gambar 1. Grafik Rendemen Persiapan Bahan

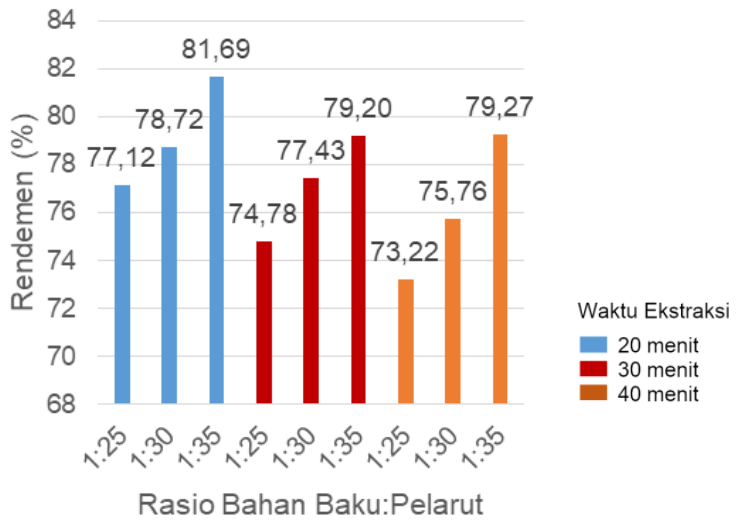

Gambar 2. Grafik Rendemen Total Ekstraksi

Gambar 1 menunjukkan bahwa bobot pada proses sortasi dan penucucian tidak berkurang banyak dari bobot awal stevia segar, namun setelah dikeringkan, rendemen daun kering hanya berkisar $21,66 \%$. Hal ini terjadi karena air yang terdapat pada daun dikeringkan 
oleh panas dari oven, sehingga bobot air di dalam daun stevia berkurang. Pada Gambar 2, dapat terllihat bahwa rendemen proses ekstraksi berkisar antara 97,76\% $99,24 \%$. Hasil ini dapat dipengaruhi oleh jenis pelarut. Pelarut air cenderung tidak mudah menguap pada suhu tinggi, sehingga bobot hasil ekstraksi tidak berkurang banyak. Pada total rendemen, rendemen tertinggi terdapat pada ekstrak yang diberikan perlakuan rasio bahan baku dan pelarut sebesar 1:35 dan waktu perebusan selama 20 menit, serta rendemen terendah terdapat pada ekstrak yang diberikan perlakuan rasio bahan baku dan pelarut sebesar 1:25 dan waktu perebusan selama 40 menit. Hal ini dapat terjadi karena jumlah air pada rasio bahan baku 1:35 lebih besar dibandingkan dengan rasio 1:25, sehingga rendemen ekstrak dengan rasio 1:35 cenderung lebih sedikit dibandingan dengan ekstrak dengan rasio 1:25.

\section{Analisis Total Padatan Terlarut}

Ekstrak stevia cair diberikan analisis total padatan terlarut. Total padatan terlarut dianalisis untuk mengetahui jumlah padatan yang terkandung dalam ekstrak. Menurut Yenrina (2015), total padatan terlarut juga dapat memberikan informasi rasa manis pada beberapa produk. Hasil analisis ragam total padatan terlarut dari ekstrak stevia cair terdapat pada Gambar 3.

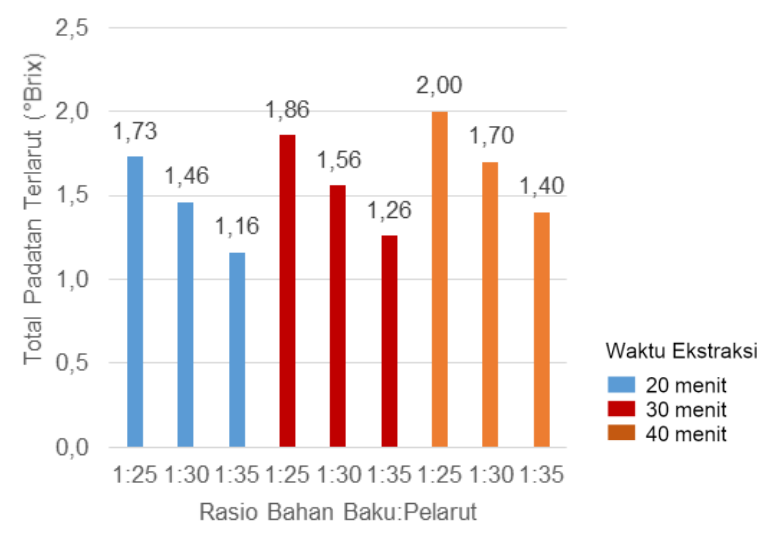

Gambar 3. Grafik Hasil Total Padatan Terlarut

Hasil pada Gambar 3 menunjukkan bahwa ekstrak dengan rasio bahan baku:pelarut sebesar 1:25 dan waktu ekstraksi selama 40 menit menghasilkan nilai total padatan terlarut tertinggi sebesar $2^{\circ}$ Brix, dan ekstrak dengan rasio bahan baku:pelarut sebesar 1:35 dan waktu ekstraksi selama 30 menit menghasilkan nilai total padatan terlarut terendah sebesar $1,16^{\circ}$ Brix. Hasil ini menunjukkan bahwa semakin banyak jumlah bahan baku (Wuryantoro dan Susanto, 2014), dan semakin lama daun stevia kontak dengan pelarut (Marlina dan Widiastuti, 2018), sehingga zat yang terekstrak akan semakin banyak. Untuk mengetahui pengaruh faktor ekstraksi terhadap total padatan terlarut, maka dilakukan analisis ragam dengan one way ANOVA. Hasil analisis ragam pada hasil total padatan terlarut terhadap jumlah bahan baku dan waktu ekstraksi terdapat pada Tabel 2 .

Tabel 2. Analisis Ragam Total Padatan Terlarut

\begin{tabular}{lcccc}
\hline \multicolumn{1}{c}{ Sumber ragam } & $\mathrm{db}$ & $\mathrm{F}_{\text {hitung }}$ & $\mathrm{F}_{0,05}$ & Sig \\
\hline Rasio bahan baku- & 2 & 6,96 & 3,55 & 0,006 \\
pelarut & 2 & 2,24 & 3,55 & 0,13 \\
Waktu ekstraksi & 4 & 0,03 & 2,93 & 0,99 \\
Rasio*Waktu & 18 & & & \\
\hline Galat & 26 & & & \\
Total & & &
\end{tabular}

Berdasarkan analisa pada Tabel 2, rasio bahan baku:pelarut berpengaruh signifikan terhadap total padatan terlarut karena $F_{\text {hitung }}$ lebih besar dibandingkan $\mathrm{F}_{0,05}$ dan nilai Sig lebih kecil dibandingkan taraf nyata 0,05 , sementara waktu ekstraksi tidak berpengaruh signifikan terhadap total padatan terlarut karena $F_{\text {hitung }}$ lebih kecil dibandingkan $\mathrm{F}_{0,05}$ dan nilai Sig lebih besar dibandingkan taraf nyata 0,05. Untuk mengetahui signifikansi pada perlakuan rasio bahan baku-pelarut, maka dilakukan uji lanjut Duncan. Hasil uji lanjut terhadap total padatan terlarut terdapat pada Tabel 3.

Tabel 3. Hasil Uji Lanjut Perlakuan Rasio Bahan Baku:Pelarut terhadap Total Padatan Terlarut

\begin{tabular}{ccc}
\hline $\begin{array}{c}\text { Rasio Bahan } \\
\text { Baku:Pelarut (b/v) }\end{array}$ & Rata-rata & Signifikansi* $^{*}$ \\
\hline $1: 25$ & 1,86 & $\mathrm{a}$ \\
$1: 30$ & 1,57 & $\mathrm{~b}$ \\
$1: 35$ & 1,27 & $\mathrm{C}$ \\
\hline
\end{tabular}

Berdasarkan Tabel 3, hasil uji lanjut dari perlakuan rasio bahan baku dan pelarut terhadap total padatan terlarut menghasilkan nilai total padatan terlarut yang berbeda nyata satu sama lain yang ditandai oleh huruf berbeda pada masing-masing perlakuan. Dapat diketahui bahwa semakin kecil rasio bahan baku-pelarut, maka hasil total padatan terlarutnya akan semakin tinggi. Hal ini dapat disebabkan oleh semakin banyak pelarut yang digunakan, maka porsi padatan dalam ekstrak akan mengalami penurunan.

\section{Analisis Warna}

Warna dari ekstrak yang dianalisis adalah kecerahannya $(L)$. Sebelum proses ekstraksi, daun stevia yang dicampurkan pada air memiliki warna kuningbening, ketika di ekstraksi, warna ekstrak berubah menjadi lebih gelap. Hal ini terjadi karena adanya komponen lain seperti tanin, klorofil, dan flavonoid (Chandra, 2015) yang terekstrak bersama dengan komponen steviosida. Menurut Wahyuni (2016), semakin tinggi steviosida yang terekstrak, maka kadar tanin juga akan semakin meningkat, sehingga warna ekstrak akan semakin gelap. Hasil hasil pengamatan kecerahan ekstrak stevia cair terdapat pada Gambar 4.

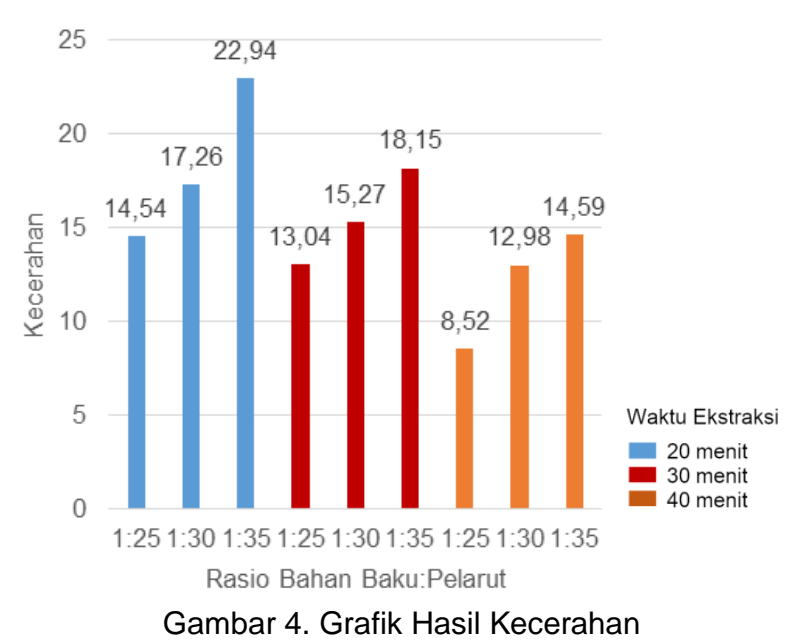

Gambar 4 menunjukkan bahwa perlakuan interaksi rasio bahan baku-pelarut sebesar 1:35 dengan waktu ekstraksi sebesar 20 menit yang menghasilkan nilai kecerahan tertinggi pada data dengan rata-rata 22,94, dan perlakuan rasio bahan baku-pelarut sebesar 1:25 
dengan waktu ekstraksi sebesar 40 menit yang menghasilkan nilai kecerahan terendah pada data dengan rata-rata 8,52. Zat yang terekstrak dari daun memiliki komponen yang memberikan warna gelap, sehingga semakin banyak jumlah daun dan semakin lama waktu ekstraksi, kecerahan ekstrak akan semakin rendah. Untuk mengetahui pengaruh faktor ekstraksi terhadap kecerahan ekstrak stevia, maka dilakukan analisis ragam dengan one way ANOVA. Hasil analisis ragam pada hasil kecerahan terdapat pada Tabel 4

Tabel 4. Analisis Ragam Kecerahan

\begin{tabular}{lcccc}
\hline Sumber ragam & $\mathrm{db}$ & $\mathrm{F}_{\text {hitung }}$ & $\mathrm{F}_{0,05}$ & Sig \\
\hline Rasio bahan baku- & 2 & 3,08 & 3,55 & 0,07 \\
pelarut & 2 & 3,08 & 3,55 & 0,07 \\
Waktu ekstraksi & 4 & 0,55 & 2,93 & 0,69 \\
Rasio*Waktu & 18 & & & \\
\hline Galat & 26 & & & \\
Total & & &
\end{tabular}

Berdasarkan Tabel 4, dapat terlihat bahwa rasio bahan baku:pelarut dan waktu ekstraksi tidak berbeda nyata terhadap kecerahan ekstrak stevia. Walaupun tidak berbeda nyata, hasil pada Gambar 4 menunjukkan bahwa semakin kecil rasio bahan baku-pelarut, dan semakin cepat waktu ekstraksi, maka kecerahan akan semakin meningkat. Selain glikosida yang memberikan rasa manis, tanaman stevia memiliki komponen pigmen yang memberikan warna, diantaranya adalah klorofil $A$ yang memberikan warna hijau, $\beta$-karotin yang menghasilkan warna kuning-oranye, tanin yang memberikan warna kuning-cokelat, dan flavonoid glikosida rutin yang memberikan warna kekuningan (Kinghorn, 2002). Zat-zat tersebut ketika diekstrak dapat ikut larut oleh pelarut, dan dapat merubah warna pelarut air yang transparan. Semakin banyak bahan baku dalam ekstrak, maka akan lebih banyak zat pigmen yang dapat dilarutkan oleh pelarut, sehingga warna ekstrak menjadi semakin gelap. Selain itu, semakin lama waktu ekstraksi, maka kontak pelarut dengan bahan baku akan semakin lama, sehingga zat seperti pigmen dalam daun stevia juga akan lebih banyak terlarut oleh pelarut, sehingga warna pada ekstrak akan semakin gelap jika diberikan perlakuan ekstraksi lebih lama.

\section{Analisis Steviosida}

Steviosida merupakan salah satu komponen glikosida yang memberikan rasa manis pada tanaman stevia. Kadar steviosida dianalisis dengan liquid chromatography-mass spectroscopy (LC-MS). LC-MS memberikan hasil dalam kromatogram, dimana kromatogram menampilkan grafik hubungan intensitas komponen terhadap waktu. Kadar dari komponen yang diinginkan dapat diketahui dari luas peak atau area yang terdapat pada kurva yang dimiliki oleh berat molekul sampel yang ingin dicari. Hasil dari kromatogram tersebut bukan merupakan hasil akhir kadar steviosida dari ekstrak, namun merupakan hasil persenan steviosida yang terdapat pada padatan pada ekstrak saja, bukan pada keseluruhan ekstrak. Hasil kadar steviosida akhir dapat dihitung dengan mengalikan nilai persenan steviosida didalam padatan dengan nilai total padatan terlarut. Hal ini dilakukan karena persenan steviosida hanya terdapat pada bagian padatan ekstrak. Hasil tersebut kemudian dikalikan dengan rasio bahan baku:pelarut. Hal ini juga dilakukan untuk mengetahui kadar steviosida keseluruhan, baik pada bagian padatan, dan bagian cair. Hasil kadar steviosida terdapat pada Gambar 5.

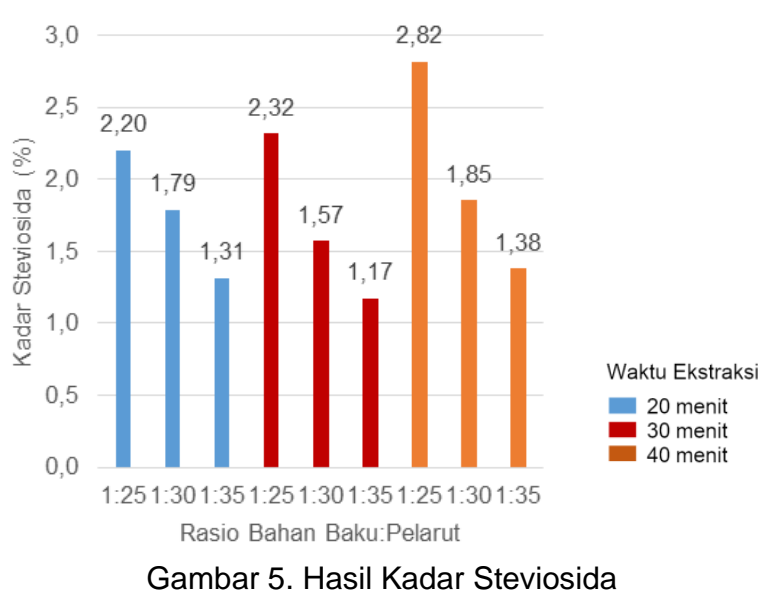

Berdasarkan Gambar 5, dapat diketahui bahwa ekstraksi dengan rasio bahan baku-pelarut sebesar 1:25 dan waktu ekstraksi selama 40 menit menghasilkan kadar steviosida tertinggi dengan nilai $2,82 \%$, dan ekstrak dengan perlakuan rasio bahan baku-pelarut sebesar 1:35 dan waktu ekstraksi selama 30 menit menghasilkan kadar steviosida terkecil dengan nilai 1,17\%. Dapat terlihat pada Gambar 5 bahwa semakin kecil rasio bahan baku, maka akan ada lebih banyak bahan baku yang dapat diekstrak oleh pelarut, sehingga kadar steviosidanya akan semakin tinggi. Kadar steviosida merupakan salah satu karakteristik yang paling penting pada ekstrak stevia cair karena kadar steviosida merupakan komponen terbesar yang memberikan rasa manis pada daun stevia, yang merupakan bahan baku dari ekstrak stevia cair ini. Sehingga semakin tinggi kadar steviosida, maka rasa manisnya akan semakin tinggi.

\section{Analisis Kemanisan}

Analisis kemanisan dilakukan pada ekstrak stevia cair dengan uji organoleptik berupa uji ranking, dimana 30 panelis tak terlatih mengurutkan sampel ekstrak stevia cair berdasarkan kemanisannya. Pada penelitian ini, nomor 1 diberikan pada sampel dengan kemanisan paling tinggi, sedangkan nomor 9 diberikan pada sampel dengan kemanisan paling rendah. Hasil rata-rata uji ranking kemanisan pada ekstrak stevia cair terdapat pada Gambar 6.

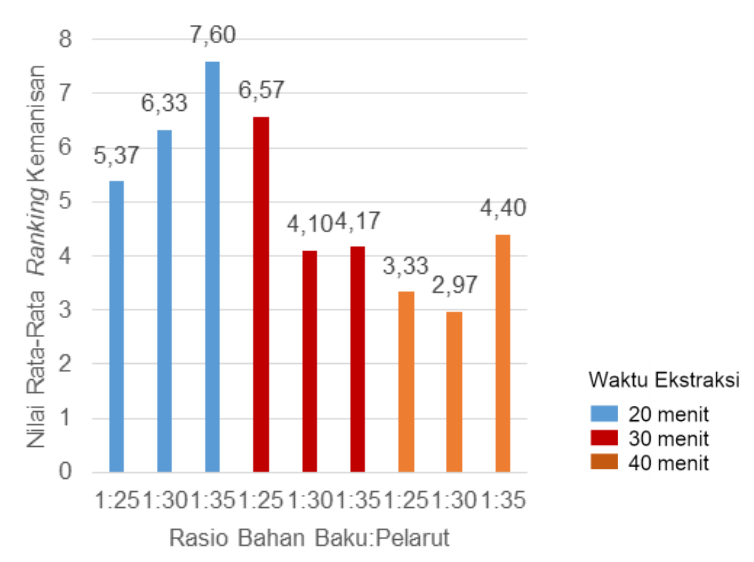

Gambar 6. Hasil Nilai Rata-Rata Ranking Kemanisan

Pada Gambar 6, dapat terlihat bahwa ekstrak yang memiliki peringkat kemanisan rata-rata paling tinggi adalah ekstrak dengan perlakuan kombinasi rasio bahan baku dan pelarut sebesar 1:30 dan waktu ekstraksi 
selama 40 menit. Ekstrak dengan rasio bahan bakupelarut 1:25 dan waktu ekstraksi 40 menit tidak menghasilkan nilai kemanisan yang lebih tinggi dibandingkan oleh ekstrak dengan rasio bahan bakupelarut 1:30 serta waktu ekstraksi 40 menit. Hal ini dapat disebabkan oleh rasa dari ekstrak dengan rasio bahan baku-pelarut 1:25 dan waktu ekstraksi 40 menit sudah melebihi ambang batas kesukaan panelis, ataupun karena adanya aftertaste yang lebih tajam dibandingkan dengan perlakuan lainnya. Hasil analisis uji ranking kemanisan pada ekstrak stevia cair dapat disimpulkan dengan merata-ratakan peringkat total dari pengamatan panelis (Lawless dan Heymann, 2010), namun untuk mengetahui signifikansi pada setiap perlakuan, maka dilakukan analisis dengan one way Anova. Hasil analisis uji ranking pada ekstrak stevia cair terdapat pada Tabel 5.

Tabel 5. Analisis Ragam Ranking Kemanisan

\begin{tabular}{lllll}
\hline Sumber ragam & $\mathrm{db}$ & $\mathrm{F}_{\text {hitung }}$ & $\mathrm{F}_{0,05}$ & Sig \\
\hline Rasio bahan baku- & 2 & 4,30 & 3,03 & 0,000 \\
pelarut & 2 & 39,97 & 3,03 & 0,014 \\
Waktu ekstraksi & 4 & 10,11 & 2,40 & 0,000 \\
Rasio*Waktu & 18 & & & \\
\hline Galat & 26 & & & \\
Total &
\end{tabular}

Berdasarkan analisa pada Tabel 5, rasio bahan baku:pelarut, waktu ekstraksi, dan interaksi antara rasio bahan baku:pelarut dan waktu ekstraksi berpengaruh signifikan terhadap ranking kemanisan karena $F_{\text {hitung lebih }}$ besar dibandingkan $\mathrm{F}_{0,05}$ dan nilai Sig lebih kecil dibandingkan taraf nyata 0,05 . Hasil analisa uji Duncan terhadap kemanisan ekstrak terdapat pada Tabel 6 dan Tabel 7 .

Tabel 6. Hasil Uji Lanjut Perlakuan Rasio Bahan Baku:Pelarut terhadap Ranking Kemanisan

\begin{tabular}{ccc}
\hline $\begin{array}{c}\text { Rasio Bahan } \\
\text { Baku:Pelarut (b/v) }\end{array}$ & Rata-rata & Signifikansi $^{*}$ \\
\hline $1: 25$ & 5,38 & $\mathrm{~b}$ \\
$1: 30$ & 4,46 & $\mathrm{a}$ \\
$1: 35$ & 5,08 & $\mathrm{ab}$ \\
\hline
\end{tabular}

Berdasarkan Tabel 6, dapat diketahui bahwa hasil uji lanjut dari perlakuan rasio bahan baku dan pelarut terhadap kemanisan menghasilkan hasil yang tidak berbeda nyata satu sama lain yang ditandai oleh huruf yang sama pada masing-masing perlakuan. Ranking kemanisan meningkat dari ekstrak dengan rasio bahan baku-pelarut 1:35 hingga rasio 1:30, namun menurun pada rasio 1:25. Hasil ini menunjukkan bahwa ekstrak dengan rasio bahan baku-pelarut 1:30 (b/v) merupakan ekstrak yang memiliki kemanisan optimum, sehingga rasio diatas 1:30 tidak memberikan efek peningkatan kesukaan kemanisan. Hal ini dapat disebabkan oleh jumlah daun stevia yang melebihi keadaan optimum menyebabkan rasa manis yang berlebih sehingga rasa manis tersebut menyerupai rasa pahit.

Tabel 7. Hasil Uji Lanjut Perlakuan Waktu Ekstraksi terhadap Ranking Kemanisan

\begin{tabular}{ccc}
\hline $\begin{array}{c}\text { Waktu Ekstraksi } \\
\text { (menit) }\end{array}$ & Rata-rata & Signifikansi $^{*}$ \\
\hline 20 & 6,43 & $\mathrm{c}$ \\
30 & 4,94 & $\mathrm{~b}$ \\
40 & 3,56 & $\mathrm{a}$ \\
\hline
\end{tabular}

Berdasarkan Tabel 18, hasil uji lanjut dari perlakuan rasio bahan baku dan pelarut terhadap waktu ekstraksi menghasilkan nilai kemanisan yang berbeda nyata satu sama lain yang ditandai oleh huruf berbeda pada masing masing perlakuan. Dapat terlihat bahwa hasil ranking kemanisan meningkat dari waktu ekstraksi 20 menit hingga waktu ekstraksi 40 menit, sehingga dapat diketahui bahwa semakin lama waktu ekstraksi, maka hasil ranking kemanisannya akan semakin tinggi. Hal ini dapat disebabkan oleh semakin lama waktu ekstraksi, maka komponen yang memberikan rasa manis pada daun stevia akan semakin banyak terekstrak oleh pelarut. Hasil uji lanjut untuk kedua faktor terhadap ranking kemanisan untuk 9 perlakuan terdapat pada Tabel 8 .

Tabel 8. Hasil Uji Lanjut Interaksi Rasio Bahan Baku:Pelarut dan Waktu Ekstraksi

\begin{tabular}{cccc}
\hline $\begin{array}{c}\text { Rasio Bahan } \\
\text { Baku:Pelarut } \\
\text { (b/v) }\end{array}$ & $\begin{array}{c}\text { Waktu } \\
\text { Ekstraksi } \\
\text { (menit) }\end{array}$ & $\begin{array}{c}\text { Rata- } \\
\text { rata }\end{array}$ & Signifikansi \\
\hline $1: 25$ & 20 & 5,37 & $\mathrm{~cd}$ \\
$1: 30$ & & 6,33 & de \\
$1: 35$ & & 7,60 & $\mathrm{f}$ \\
$1: 25$ & \multirow{2}{*}{30} & 6,57 & ef \\
$1: 30$ & & 4,10 & ab \\
$1: 35$ & & 4,17 & $\mathrm{~b}$ \\
$1: 25$ & \multirow{2}{*}{40} & 2,33 & $\mathrm{ab}$ \\
$1: 30$ & & 4,40 & $\mathrm{a}$ \\
$1: 35$ & & & $\mathrm{ab}$ \\
\hline
\end{tabular}

Hasil uji lanjut Duncan antara rasio bahan bakupelarut dan waktu ekstraksi terhadap ranking kemanisan menghasilkan nilai yang tidak berbeda nyata satu sama lain yang ditandai oleh huruf yang sama pada masingmasing perlakuan. Perlakuan yang menghasilkan ranking kemanisan tertinggi terdapat pada ekstrak dengan rasio bahan baku-pelarut 1:30 dan waktu ekstraksi 40 menit. Hasil ini menandakan bahwa ekstrak dengan rasio bahan baku-pelarut 1:30 dan waktu ekstraksi 40 menit menghasilkan kemanisan yang paling optimum bagi panelis. Untuk itu ekstrak dengan bahan baku-pelarut 1:30 dan waktu ekstraksi 40 menit akan digunakan sebagai sampel pada pengujian umur simpan sensori ekstrak stevia cair.

\section{Perlakuan Terbaik}

Berdasarkan hasil analisa perlakuan terbaik dengan metode indeks efektivitas, diketahui bahwa ekstrak dengan rasio bahan baku:pelarut 1:25 dan waktu ekstraksi 40 menit merupakan ekstrak dengan perlakuan terbaik. Ekstrak dengan rasio bahan baku:pelarut 1:25 dan waktu ekstraksi 40 menit memiliki total padatan terlarut rata-rata $2^{\circ}$ Brix, kecerahan 8,25 , kadar steviosida $2,82 \%$, dan ranking kemanisan 3,33 .

\section{Analisis Kesamaan Kemanisan}

Pengujian kemanisan dilakukan dengan metode magnitude estimation. Sepuluh orang panelis terlatih menilai kemanisan dari lima konsentrasi ekstrak stevia cair perlakuan rasio bahan baku:pelarut 1:30 (b/v) dan waktu ekstraksi 40 menit, yang dibandingkan dengan sampel kontrol (sukrosa 10\%) yang memiliki nilai 100. Hasil penilaian kemanisan (S) diubah dalam bentuk log, kemudian diplotkan dengan konsentrasi (C) pada grafik.

Hasil regresi persamaan power dari kemanisan sukrosa dan ekstrak stevia memiliki persamaan yang menghasilkan variabel y yang merupakan penilaian kemanisan (S), variabel a yang merupakan intersep, variabel $x$ yang merupakan konsentrasi $(C)$, dan variabel $\mathrm{n}$ yang merupakan slope. Nilai kemanisan (S) dari 
sukrosa untuk konsentrasi (C) $10 \%$ adalah 2. Untuk mengetahui konsentrasi ekstrak stevia yang memiliki tingkat kemanisan (S) yang sama pada sukrosa, maka pada persamaan kemanisan ekstrak stevia, nilai $\mathrm{C}$ dicari dengan memasukkan nilai $S=2$. Hasil tingkat kemanisan ekstrak stevia cair dengan sukrosa $10 \%$ terdapat pada Tabel 9.

Tabel 9. Hasil Kesamaan Kemanisan

\begin{tabular}{lcccc}
\hline $\begin{array}{c}\text { Jenis } \\
\text { Pemanis }\end{array}$ & a & n & C & $\begin{array}{c}\text { Tingkat } \\
\text { Kemanisan } \\
\text { (x sukrosa) } \\
\text { Sukrosa }\end{array}$ \\
\hline Sukrosa & 1,2702 & 0,2054 & 10 & 1 \\
Stevia & 1,2513 & 0,2285 & 8,46 & 120 \\
\hline
\end{tabular}

Hasil perhitungan magnitude estimation menunjukkan bahwa larutan sukrosa dengan konsentrasi 10\% memiliki tingkatan rasa manis yang sama dengan ekstrak stevia cair perlakuan rasio bahan baku:pelarut 1:30 (b/v) dan waktu ekstraksi 40 menit pada konsentrasi 8,46\%. Sehingga dapat disimpulkan bahwa ekstrak stevia cair memiliki tingkat kemanisan 1,2 lebih manis dari larutan sukrosa $10 \%$, dan jika ekstrak dikentalkan dengan jumlah air pengenceran, yaitu 100 mililiter, maka nilai tingkat kemanisan menjadi 120 kali.

\section{Analisis Umur Simpan}

Analisis umur simpan dilakukan dengan metode sensory shelf-life estimation selama 28 hari dan dievaluasi dengan reversed design. Mutu yang diamati diantaranya adalah peningkatan warna gelap dan kepahitan. Hasil pengamatan diplotkan antara lama penyimpanan dengan peningkatan kepahitan dan peningkatan warna gelap pada Orde Nol dan Satu. Orde reaksi yang digunakan ditentukan berdasarkan nilai regresi pada grafik.

Grafik Orde Nol digunakan karena memiliki nilai regresi yang lebih besar dibandingkan dengan grafik Orde Satu. Untuk itu perhitungan umur simpan menggunakan persamaan dari grafik Orde Nol. Variabel y dari persamaan dapat dihubungkan dengan parameter kritis mutu $(7,5)$, variabel a adalah intersep, variabel $b$ adalah slope, dan variabel $x$ sebagai umur simpan. Hasil perhitungan umur simpan terhadap peningkatan kepahitan dan peningkatan warna gelap terdapat pada Tabel 10.

Tabel 10. Hasil Umur Simpan

\begin{tabular}{|c|c|c|c|c|}
\hline Mutu & Persamaan & $a$ & $b$ & $x$ (hari) \\
\hline Kepahitan & $\begin{array}{l}y=0,2857 x \\
+3,92\end{array}$ & 0,2857 & 3,92 & 12,531 \\
\hline $\begin{array}{l}\text { Warna } \\
\text { Gelap }\end{array}$ & $\begin{array}{l}y=0,32 x+ \\
3,22\end{array}$ & 0,32 & 3,22 & 13,375 \\
\hline
\end{tabular}

Hasil variabel $x$ yang terdapat pada Tabel 18 menunjukkan umur simpan ekstrak dalam hari. Hasil tersebut menunjukkan bahwa ekstrak stevia cair memiliki umur simpan 12,531 hari pada mutu peningkatan kepahitan, dan 13,375 hari pada mutu peningkatan warna gelap. Dari kedua hasil umur simpan, umur simpan yang lebih singkat disimpulkan sebagai umur simpan produk, untuk itu umur simpan ekstrak stevia cair yang ditetapkan adalah 12,531 hari

\section{KESIMPULAN}

Ekstraksi dengan rasio bahan baku:pelarut 1:25 (b/v) dan waktu ekstraksi selama 40 menit menghasilkan ekstrak dengan karakteristik terbaik, dengan nilai total padatan terlarut $2^{\circ}$ Brix, kecerahan 8,25 , kadar steviosida $2,82 \%$, dan ranking kemanisan 3,33 , serta umur simpan ekstrak stevia cair pada penelitian ini adalah 12,531 hari.

\section{DAFTAR PUSTAKA}

AOAC. (1999). Official Methods of Analysis of the Association of Official of Analitycal Chemist. Washington D.C.: AOAC, Inc.

Cardello, H. M., Da Silva, M. A., Damasio, M. H. (1999). Measurement of the Relative Sweetness of Stevia Extract, Aspartame and Cyclamate/Saccharin Blend as Compared to Sucrose at Different Concentrations. Plant Foods for Human Nutrition, $119-130$.

Chandra, A. (2015). Studi awal ekstraksi Batch daun Stevia rebaudiana dengan variabel jenis pelarut dan temperatur ekstraksi. Seminar Nasional Masyarakat Biodiversitas Indonesia (pp. 114-119). Surakarta: Universitas Sebelas Maret.

Gasmalla, M. A., Yang, R., Amadou, I., \& Hua, X. (2014). Nutrirional Composition of Stevia rebaudiana Bertoni Leaf: Effect of Drying Method. Tropical Journal of Pharmaceutical Research, 61-65.

Gimenez, A., Ares, F., Ares, G. 2012. Sensory Shelf Life Estimation: A Review of Current Methodological Approaches. Food Research International, 311-325.

Hunter Associates Laboratory. (2010). ColorFlexEZ Spesification. Retrieved from HunterLab Website: http://www.hunterlab.com/colorflex-ezspesifications.pdf

Kinghorn, D. (2002). Stevia Overview. In D. Kinghorn, Stevia: The genus Stevia (pp. 1-17). London: Taylor \& Francis.

Lawless, H. T., \& Heymann, H. (2010). Sensory Evaluation of Food. New York: Springer.

Lemus-Mondaca, R., Ah-Hen, K., Vega-Galvez, A., Honores, C., \& Moraga, N. O. (2015). Stevia rebaudiana Leaves: Effect of Drying Process Temperature on Bioactive Components, Antioxidant Capacity and Natural Sweeteners. Plant Foods for Human Nutrition.

Marlina, A., \& Widiastuti, E. (2018). Pembuatan Gula Cair Rendah Kalori dari Daun Stevia rebaudiana Bertoni secara Ekstraksi Padat-Cair. Prosiding Industrial Research Workshop and National Seminar, 149154.

Muliana, N. S. (2017). Kajian Pengaruh Suhu Ekstraksi terhadap Mutu Gula Stevia (Stevia rebaudiana Bertoni). Sumedang: Universitas Padjadjaran.

OECD. (2018). OECD-FAO Agricultural Outlook. Retrieved from OECD iLibrary: https://www.oecdilibrary.org/agriculture-and-food/data/oecdagriculture-statistics/oecd-fao-agricultural-outlookedition-2018_d4bae583-en

Shah, R., Jager, L. S., Begley, T. H. (2012). Simultaneous Determination of Steviol and Steviol Glycosides by Liquid Chromatography-Mass Spectrometry. Food Additives \& Contaminants: Part A, 1861-1871.

Thomas, J. E., \& Glade, M. J. (2010). Stevia: It's Not Just About Calories. The Open Obesity Journal, 101109.

Toledo, R. T. (1991). Fundamentals of Food Processing Engineering. New York: Chapman\&Hall.

United States Department of Agriculture. (2015). Cut Down on Added Sugars. Retrieved from Dietary Guidelines for Americans: 
https://health.gov/dietaryguidelines/2015/resources/

DGA_Cut-Down-On-Added-Sugars.pdf

Wahyuni, F. (2016). Ekstraksi Daun Stevia (Stevia rebaudiana) menggunakan Microwave. Bogor: Institut Pertanian Bogor.

Whitehouse, C. R., Boullata, J., \& McCauley, L. A (2008). The Potential Toxicity of Artificial Sweetener. AAOHN Journal, 251-259.

Wuryantoro, H., \& Susanto, W. H. (2014). Penyusunan Standard Operating Procedures Industri Rumah Tangga Pangan Pemanis Alami Instan Sari Stevia (Stevia rebaudiana). Jurnal Pangan dan Agroindustri, 76-87.

Yenrina, R. (2015). Metode Analisis Bahan Pangan dan Komponen Bioaktif. Padang: Andalas Univerisity Press. 